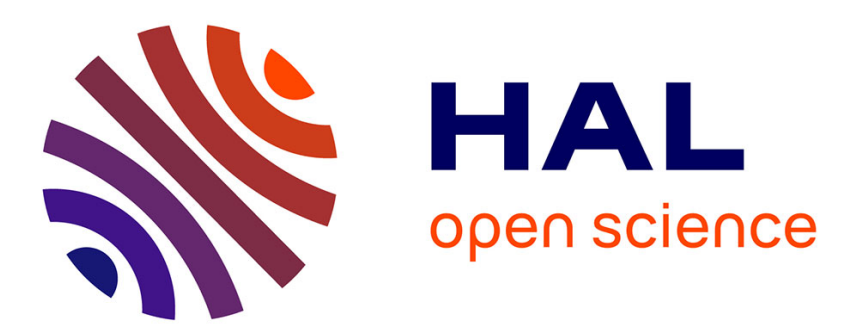

\title{
Affinity of chlordecone and chlordecol for human serum lipoproteins
}

\author{
Matthieu Delannoy, Jean-Michel Girardet, Fathia Djelti, Frances Yen Potin, \\ Celine Cakir-Kiefer
}

\section{- To cite this version:}

Matthieu Delannoy, Jean-Michel Girardet, Fathia Djelti, Frances Yen Potin, Celine Cakir-Kiefer. Affinity of chlordecone and chlordecol for human serum lipoproteins. Environmental Toxicology and Pharmacology, 2020, 80, pp.1-4. 10.1016/j.etap.2020.103486 . hal-02925906

\section{HAL Id: hal-02925906 \\ https://hal.univ-lorraine.fr/hal-02925906}

Submitted on 14 Sep 2020

HAL is a multi-disciplinary open access archive for the deposit and dissemination of scientific research documents, whether they are published or not. The documents may come from teaching and research institutions in France or abroad, or from public or private research centers.
L'archive ouverte pluridisciplinaire HAL, est destinée au dépôt et à la diffusion de documents scientifiques de niveau recherche, publiés ou non, émanant des établissements d'enseignement et de recherche français ou étrangers, des laboratoires publics ou privés. 


\title{
Affinity of chlordecone and chlordecol for human serum lipoproteins
}

\author{
Matthieu Delannoy ${ }^{1}$, Jean-Michel Girardet $^{2}$, Fathia Djelti ${ }^{1}$, Frances T. Yen ${ }^{1 *}$, Céline \\ Cakir-Kiefer ${ }^{1, *}$ \\ ${ }^{*}$ co-senior authors \\ ${ }^{1}$ Université de Lorraine, INRAE, Unité de Recherche Animal et Fonctionnalités
des Produits Animaux (UR AFPA), USC 340, Nancy F-54000, France
}

${ }^{2}$ Université de Lorraine, INRAE, Interactions Arbres/Micro-organismes (IAM), UMR 1136, F-54000 Nancy, France

Environmental Toxicology and Pharmacology

\begin{abstract}
Chlordecone (CLD) is a chlorinated persistent organic pollutant (POP) whose presence despite the 1993 ban in agriculture areas has caused numerous public health concerns. CLD accumulates in the liver, and the CLD metabolite, chlordecol (CLD-OH) is found in bile, an important site of excretion for cholesterol transported to the liver via lipoproteins. Here, we studied the real-time molecular interaction between CLD and CLD-OH with human serum lipoproteins, LDL and HDL. While no interaction was detected between CLD and HDL, or between CLD-OH and LDL, relatively high specific affinities were observed between CLD and CLD-OH for LDL and HDL, respectively.
\end{abstract}

\section{Introduction}

Chlordecone (CLD) is a chlorinated Persistent Organic Pollutant (POP) particularly recalcitrant to biological degradation (Cabidoche et al., 2009; Chaussonnerie et al., 2016; Matolcsy et al., 1988). Its wide use as an insecticide from 1972 to 1993 resulted in high contamination levels of banana plantation soils (Cabidoche et al., 2009; Levillain et al., 2012) which is predicted to last for several centuries (Cabidoche et al., 2009). Comprehensive ecosystem analysis revealed that CLD is one of the most frequently detected chlorinated pesticide in wild birds, reared animals, fishes in nearby contaminated areas or even at the coast (Cavelier, 1980).

In view of this, contamination in humans was inevitable, and impregnation was demonstrated by the Kannari study reporting that more than $90 \%$ of the total samples collected from French West Indies population contained mean CLD levels of $1.24 \mu \mathrm{g} \cdot \mathrm{L}^{-1}$ in Guadeloupe and $1.84 \mu \mathrm{g} \cdot \mathrm{L}^{-1}$ in
Martinique (Dereumeaux and Saoudi, 2018). Epidemiological studies suggest that contamination may have a serious impact on health, including increased incidence of prostate cancer (Multigner et al., 2016) as well as neurodevelopment disorders (Cordier et al., 2015). To evaluate the mode of action of CLD requires a better understanding of its bioavailability in vivo.

It is known that unlike other organochlorine pesticides, CLD concentrations are higher in liver than in fatty tissues in animals (Delannoy et al., 2019). Studies revealed that chlordecol (CLD-OH), a metabolite of CLD, was highly concentrated in the bile, which is also the means by which cholesterol is transported to the intestine for excretion (Soine et al., 1984, 1983). Cholesterol is taken up by the liver in the form of lipoproteins that circulate in the blood, which may also be the means of transport for CLD. Indeed, binding studies using ${ }^{14} \mathrm{C}$-CLD found that CLD was able to bind to lipoproteins, with a relative distribution of plasma protein $\geq \mathrm{HDL}>\mathrm{LDL} \geq \mathrm{VLDL}$ (Soine et al., 
1982), suggesting a potential difference of affinity for the different lipoprotein fractions. The objective of this study was to perform real-time analysis of molecular interaction between CLD or CLD-OH and isolated human lipoproteins, LDL and HDL, using switchSENSE® technology.

\section{Materials and Methods: Preparation of lipoproteins}

Lipoproteins from pooled human plasma were prepared by sequential ultracentrifugation (LDL, d1.006 g/mL - d1.063 g/mL, HDL, d1.063- d1.21 $\mathrm{g} / \mathrm{mL}$ ) (Schumaker and Puppione, 1986). Lipoproteins were dialyzed against $40 \mathrm{mM}$ $\mathrm{NaCl}$ containing $10 \mathrm{mM} \mathrm{Na}_{2} \mathrm{HPO}_{4}$ solution, $\mathrm{pH}$ 7.4, stored at $4^{\circ} \mathrm{C}$ under $\mathrm{N}_{2}$ before use within 1 week following preparation. Protein concentration was determined using the modified Lowry assay (Markwell et al., 1981). Lipoprotein samples (10 $\mu \mathrm{g}$ protein) were denatured in Laemmli buffer, and separated on $10 \%$ SDS PAGE, followed by staining with Blue Coomassie to obtain the apolipoprotein profile of each lipoprotein fraction.

\section{Time-resolved measurements}

\section{Lipoproteins-DNA preparation and quantification}

The lipoproteins were immobilized on an electroswitchable DNA chip MPC-48-2-R1-S placed into a biosensor analyzer switchSENSE® DRX (Dynamic Biosensors $\mathrm{GmbH}$, Planegg, Germany) according to Langer et al. (2013). Covalent conjugates between HDL or LDL and a 48 mer ssDNA were prepared with the amine coupling kit (Dynamic Biosensors) and purified by anion-exchange chromatography (ÄKTA-Start ${ }^{\mathrm{TM}}$ system, GE Healthcare, Uppsala, Sweden). Conjugate concentration was determined at $260 \mathrm{~nm}$ with a ND1000 Nanodrop spectrophotometer (LabTech, Palaiseau, France).

\section{Chip complexation of the lipoproteins- DNA conjugates}

The lipoproteins-DNA conjugates were then prepared as a $200 \mathrm{nM}$ solution in $10 \mathrm{mM}$ $\mathrm{NaH}_{2} \mathrm{PO}_{4} / \mathrm{Na}_{2} \mathrm{HPO}_{4}$ buffer, pH 7.4, containing 40 $\mathrm{mM} \mathrm{NaCl}$ (P40 buffer). Conjugate $(25 \mu \mathrm{L})$ was injected into the chip to form fluorescent nanolevers. From switching dynamics of the conjugates, the hydrodynamic diameter $\left(D_{H}\right)$ of the DNA.

HDL and LDL was determined using the Lollipop mathematical model (switchANALYSIS $\circledast$ software).

\section{Results}

Interaction assessment of the lipoproteins-DNA conjugates with chlordecone or chlordecol.

To perform fluorescence static measurements in the presence of the analytes, serial dilutions of CLD or CLD-OH at $200 \mu \mathrm{M}$ in P40 buffer containing $1 \%$ methanol were injected into the microfluidic at flow rate of $5 \mu \mathrm{L}$. $\mathrm{min}^{-1}$ for $5 \mathrm{~min}$ $\left(37^{\circ} \mathrm{C}\right)$ and $\mathrm{P} 40$ buffer containing $1 \%$ methanol was then injected at $30 \mu \mathrm{L} \cdot \mathrm{min}^{-1}$ for $60 \mathrm{~min}$ to determine the affinity constant $K_{\mathrm{D}}=k_{\text {off }} / k_{\text {on }}$ of each complex from the association $\left(k_{\text {on }}\right)$ and dissociation $\left(k_{\text {off }}\right)$ kinetics constants. Data of blank controls (P40 containing $1 \%$ methanol with no analyte) were subtracted to normalize the signal. Potential unspecific binding of CLD and CLD-OH onto the DNA moiety of the nanolevers was verified with lipoprotein-free dsDNA nanolevers under the same experimental conditions. All curves were analyzed by nonlinear fitting of single-exponential functions with the switchANALYSIS ${ }^{8}$ software. Each experiment was performed with two different preparations of lipoproteins.

\section{Characterization and conjugation of} lipoproteins to DNA chip

The purity of the lipoprotein samples was confirmed by the presence of apolipoprotein (apo)B100 in LDL and apoAl in HDL detected by Coomassie Blue staining following separation by SDS-PAGE (Supplementary data 1).

The lipoproteins were covalently conjugated with 48-mer ssDNA and the conjugates were successfully purified by anion-exchange chromatography (Supplementary data, 2).

High frequency dynamic electrical switching mode allowed the measure of hydrodynamic friction to assess absolute size and shape of interacting biomolecules and thus allowing determination of the size of the lipoproteins (Supplementary data 3). Here, purified HDL displayed a hydrodynamic diameter $\left(D_{H}\right)$ of $7.4 \mathrm{~nm} \pm 0.2 \mathrm{~nm}(\mathrm{n}=3)$ confirming the conjugation of the HDL to the DNA. However, due to limits of the dynamic measurement with switchSENSE® technology, the $D_{\mathrm{H}}$ of LDL was determined to be $>14 \mathrm{~nm}$, which is nevertheless consistent with the literature (18-25 nm) (Gotto et al., 1986), confirming the conjugation of the LDL to 


\section{Interaction between chlordecone chlordecol with lipoproteins $L D L$ or HDL}

Real-time molecular interactions were investigated between the lipoproteins HDL or LDL used as ligands and CLD or CLD-OH as analytes. Interaction between LDL or HDL and CLD or CLD$\mathrm{OH}$ was measured using the lipoprotein-conjugated chips and switchSENSE ${ }^{\circledR}$ technology. No interaction was detected either between $\mathrm{HDL}$ and CLD or between LDL and CLD-OH (Fig. 1; Table 1). However, binding between HDL and CLD-OH and between LDL and CLD was observed, yielding affinity constants in the $\mu \mathrm{M}$ range $\left(K_{\mathrm{D}}=1.50 \pm 0.08\right.$ $\mu \mathrm{M}$ and $0.91 \pm 0.07 \mu \mathrm{M}$, respectively; Table I). The association rates were relatively fast ( $k_{\text {on }}$ of $c a$. 560 $\mathrm{M}^{-1} \mathrm{~s}^{-1}$ ), whereas slightly less than an hour was needed to fully release the analytes ( $k_{\text {off }}$ with a degree of magnitude of $10^{-4} \mathrm{~s}^{-1}$ ), suggesting reversible interactions between the lipoproteins and their specific analytes.

Table 1: Kinetics and affinity constants of lipoproteins HDL and LDL interacting with CLD or CLD-OH (n.b.: no binding).

\begin{tabular}{lcc}
\cline { 2 - 3 } & $\mathrm{HDL}$ & $\mathrm{LDL}$ \\
\hline $\mathrm{CLD}$ & n.b. & $557 \pm 20$ \\
$k_{\text {on }}\left(\mathrm{M}^{-1} \mathrm{~s}^{-1}\right)$ & n.b. & $(5.05 \pm 0.36) 10^{-4}$ \\
$k_{\text {off }}\left(\mathrm{s}^{-1}\right)$ & n.b. & $0.91 \pm 0.07$ \\
$K_{\mathrm{D}}(\mu \mathrm{M})$ & & \\
$\mathrm{CLD}-\mathrm{OH}$ & & n.b.
\end{tabular}
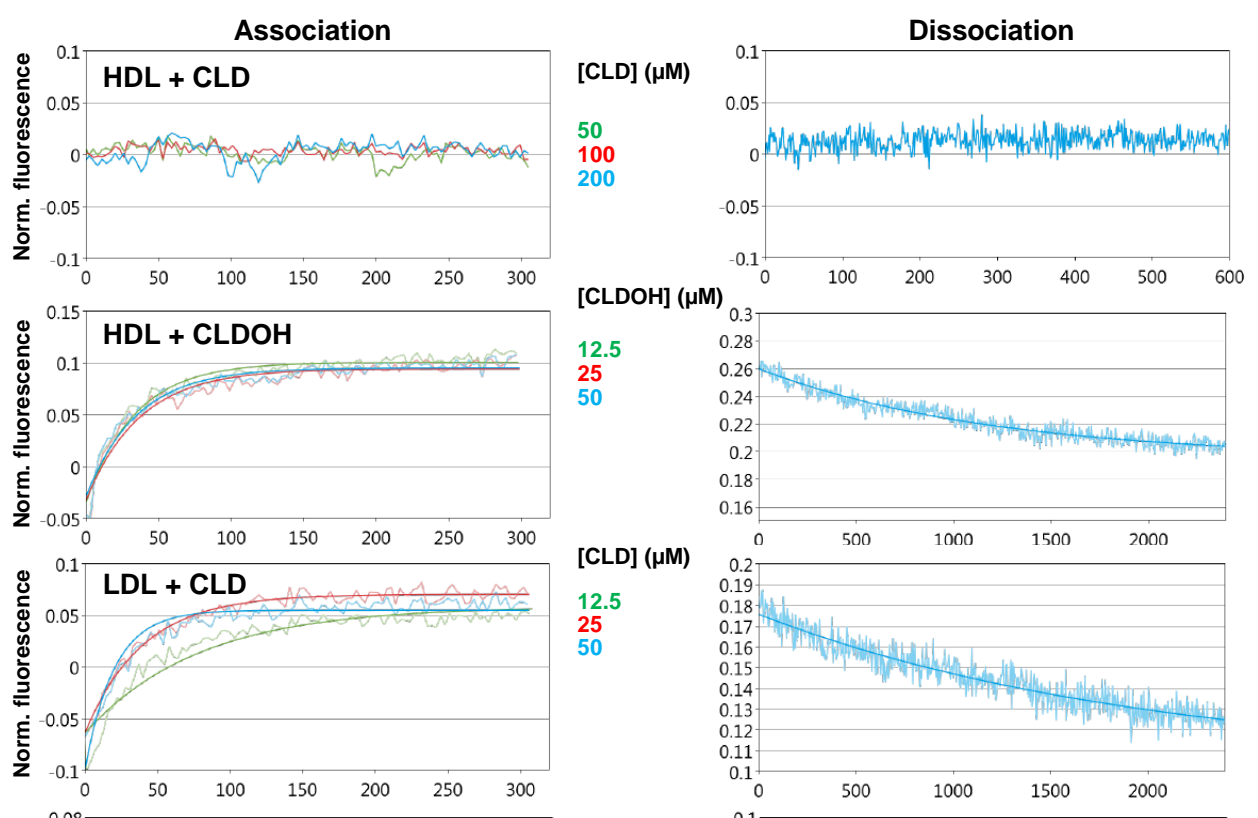

CLD is metabolized following a 2-step reaction: reduction of CLD to CLD-OH and subsequent conjugation to sulfonide and glucuronide compounds leading to more hydrophilic compounds. The efficiency of each step is highly dependent of the species (Molowa et al., 1986a, 1986b). For humans, previous papers reported amounts between 10 to $58 \%$ of conjugated CLD and $2-10 \%$ of conjugated CLD-OH (Boylan et al., 1979; Fariss et al., 1980). Overall, the levels ofCLD relative to CLD-OH vary within $25 \%$ to $75 \%$. The bile appears to be the most concentrated matrix (Fariss et al., 1980; Houston et al., 1981; Saint-Hilaire, 2018, p.; Soine et al., 1983) whereas few CLD-OH were found in plasma. Here, we report for the first time the use of switchSENSE® technology for the study of molecular interactions of analytes with intact human lipoprotein particles. Interestingly, the results show binding preference of LDL for CLD, and HDL for CLD-OH. The difference in the affinity of the lipoproteins for CLD and CLD-OH may be due to the different composition of each lipoprotein. LDL is composed of $80 \%$ lipid and $20 \%$ protein, the latter being the highly hydrophobic apoB. On the other hand, HDL contains $50 \%$ lipid and $50 \%$ protein (apoAl, see
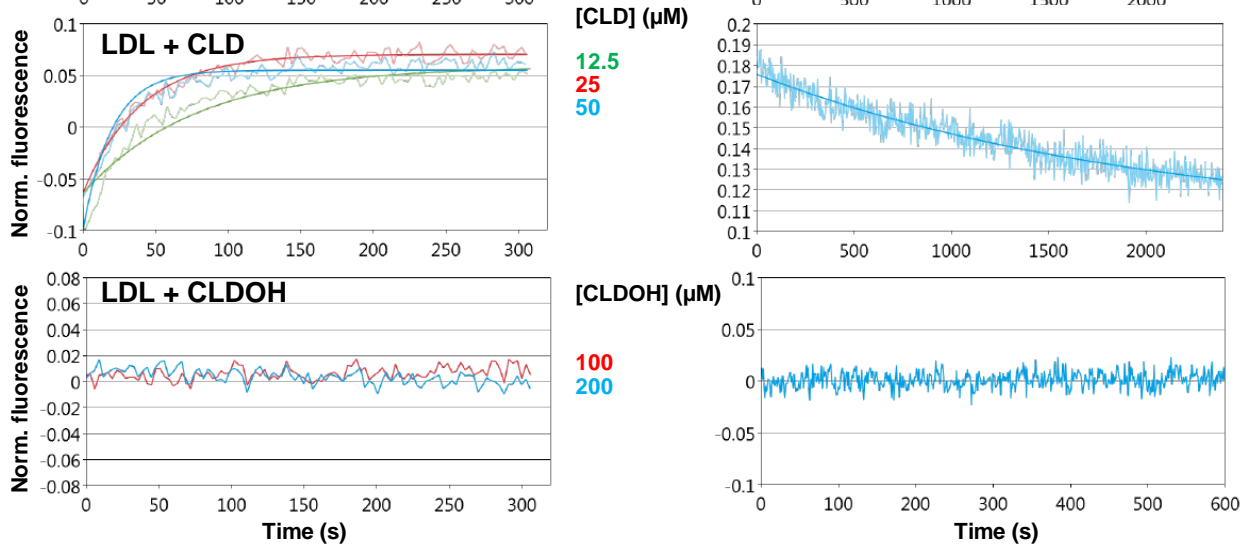

Figure 1. Real-time molecular interaction measurement between HDL or LDL and chlordecone (CLD) or chlordecol (CLDOH) using the switchSENSE® technology. The raw data are superimposed by global exponential fits for various concentrations of each analyte. The $k_{\text {on }}$, $k_{\text {off }}$ and $K_{D}$ were determined for each kinetics measurement (Norm: 
supplementary data 1 ). With its higher content of protein relative to that of LDL, HDL can be considered as less lipophilic, which may explain the preferential interaction of the hydrophilic CLD$\mathrm{OH}$, while CLD demonstrates preferential binding to the lipophilic LDL. A previous study investigated the interaction between lipoproteins and radioactively labeled CLD and reported a higher amount of ${ }^{14} \mathrm{C}-\mathrm{CLD}$ with $\mathrm{HDL}$ relative to $\mathrm{LDL}$ (Soine et al., 1982). However, distribution of CLD amongst the lipoproteins was measured after incubation of CLD with total serum, therefore under conditions when equilibrium was achieved. The present study provides further insight concerning the real time interaction and kinetics constants of this interaction using purified lipoproteins and the new switchSENSE® advanced technology.

Results revealed a $K_{D}$ of LDL and HDL for CLD and CLD-OH, respectively, in the range of $1 \mu \mathrm{M}$. This is a relatively high affinity and would be consistent with a role of the lipoproteins in the transport of the pesticide to its target tissue. In view of HDL's role in lipid transport from peripheral tissues to the liver, we would postulate that its preferential affinity for CLD-OH may facilitate lipoprotein-mediated delivery of CLD metabolite to the liver for further metabolism and excretion via the bile (Fariss et al., 1980; Houston et al., 1981; Soine et al., 1983). While LDL is primarily catabolized in the liver, the exclusive CLD affinity for LDL could lead in its transport to other peripheral tissues where CLD could be stored or metabolized before excretion.

Lipoprotein receptors are key players in the regulation of lipid homeostasis, and we hypothesize that lipid homeostasis may also be disrupted due to the interaction between lipoproteins and CLD or CLD-OH. We had previously shown that benzo[a]pyrene can affect binding of lipoproteins to hepatic lipoprotein receptors contributing to modifications in lipid status such as increased weight gain in mice (Layeghkhavidaki et al., 2014). Moreover, CLD altered tissue distribution of exogenous cholesterol with a preferential accumulation detected in adipose tissue (Lee et al., 2008). This disruption of lipid homeostasis may lead to dyslipidemias, which are significant risk factors for metabolic (obesity and diabetes), cardiovascular, and neurodegenerative diseases.

\section{Conclusion}

In conclusion, the present study on the affinity of CLD and CLD-OH for LDL and HDL lipoproteins using the switchSENSE® technology provide useful data on the specificity of interaction of CLD with LDL and CLD-OH with HDL, allowing the development of a distribution model of CLD and CLD-OH in human tissues and a better understanding of CLD bioavailabity in humans. These results are a key step for a better understanding of CLD bioavailability.

\section{References}

Boylan, J.J., Cohn, W.J., Egle Jr, J.L., 1979. Excretion of chlordecone by the gastrointestinal tract: Evidence for a nonbiliary mechanism. Clin. Pharmacol. Ther. 25, 579-585.

Cabidoche, Y.-M., Achard, R., Cattan, P., Clermont-Dauphin, C., Massat, F., Sansoulet, J., 2009. Long-term pollution by chlordecone of tropical volcanic soils in the French West Indies: A simple leaching model accounts for current residue. Environ. Pollut., Special Issue Section: Ozone and Mediterranean Ecology: Plants, People, Problems 157, 1697-1705. https://doi.org/10.1016/j.envpol.2008.12.015

Cavelier, N., 1980. Contamination of fauna by organochlorine pesticides. In: Kermarrec A (Ed): Current level of the biological chains in Guadeloupe: pesticides and heavy metals 1979_ 1980, INRA, French Ministry of the Environment [in French].

Chaussonnerie, S., Saaidi, P.-L., Ugarte, E., Barbance, A., Fossey, A., Barbe, V., Gyapay, G., Brüls, T., Chevallier, M., Couturat, L., Fouteau, S., Muselet, D., Pateau, E., Cohen, G.N., Fonknechten, N., Weissenbach, J., Le Paslier, D., 2016. Microbial Degradation of a Recalcitrant Pesticide: Chlordecone. Front. Microbiol. 7. https://doi.org/10.3389/fmicb.2016.02025

Cordier, S., Bouquet, E., Warembourg, C., Massart, C., Rouget, F., Kadhel, P., Bataille, H., Monfort, C., Boucher, O., Muckle, G., Multigner, L., 2015. Perinatal exposure to chlordecone, thyroid hormone status and neurodevelopment in infants: The Timoun cohort study in Guadeloupe (French West Indies). Environ. Res. 138, 271278. https://doi.org/10.1016/j.envres.2015.02.021

Delannoy, M., Techer, D., Yehya, S., Razafitianamaharavo, A., Amutova, F., Fournier, A., Baroudi, M., Montarges-Pelletier, E., Rychen, G., Feidt, C., 2019. Evaluation of two contrasted activated carbon-based sequestration strategies to reduce soil-bound chlordecone bioavailability in 
piglets. Environ. Sci. Pollut. Res. chlordecone reductase from human liver. J. Biol. https://doi.org/10.1007/s11356-019-06494-z Chem. 261, 12624-12627.

Dereumeaux, C., Saoudi, A., 2018. Imprégnation Molowa, D.T., Wrighton, S.A., Blanke, R.V., de la population antillaise par la chlordécone et certains composés organochlorés en 2013/2014. Etude Kannari. Saint-Maurice: Santé Publique France.

Fariss, M.W., Blanke, R.V., Saady, J.J., Guzelian, P.S., 1980. Demonstration of major metabolic pathways for chlordecone (kepone) in humans. Drug Metab. Dispos. 8, 434-438.

Gotto, A.M., Pownall, H.J., Havel, R.J., 1986. Introduction to the plasma lipoproteins. Methods Enzymol. 128 , 3-41. https://doi.org/10.1016/0076-6879(86)28061-1

Houston, T.E., Mutter, L.C., Blanke, R.V., Guzelian, P.S., 1981. Chlordecone alcohol formation in the mongolian gerbil(Meriones unguiculatus): A model for human metabolism of chlordecone (Kepone). Fundam. Appl. Toxicol. 1, 293-298.

0590(81)80132-7

Layeghkhavidaki, H., Lanhers, M.-C., Akbar, S., Gregory-Pauron, L., Oster, T., Grova, N., Appenzeller, B., Jasniewski, J., Feidt, C., Corbier, C., Yen, F.T., 2014. Inhibitory action of benzo[a]pyrene on hepatic lipoprotein receptors in vitro and on liver lipid homeostasis in mice. PloS One 9, e102991. https://doi.org/10.1371/journal.pone.0102991

Guzelian, P.S., 1986b. Characterization of a unique aldo-keto reductase responsible for the reduction of chlordecone in the liver of the gerbil and man. J. Toxicol. Environ. Health 17, 375384. https://doi.org/10.1080/15287398609530832 Multigner, L., Kadhel, P., Rouget, F., Blanchet, P., Cordier, S., 2016. Chlordecone exposure and adverse effects in French West Indies populations. Environ. Sci. Pollut. Res. Int. 23, 38. https://doi.org/10.1007/s11356-015-4621-5

Saint-Hilaire, M., 2018. Toxicocinétique de la chlordécone chez la brebis (These de doctorat). Université de Lorraine.

Schumaker, V.N., Puppione, D.L., 1986. Sequential flotation ultracentrifugation. Methods Enzymol. 128, 155-170. https://doi.org/10.1016/0076-6879(86)28066-0

Soine, P.J., Blanke, R.V., Guzelian, P.S., Schwartz, C.C., 1982. Preferential binding of chlordecone to the protein and high density lipoprotein fractions of plasma from humans and other species. J. Toxicol. Environ. Health 9, 107118. https://doi.org/10.1080/15287398209530146 Soine, P.J., Blanke, R.V., Schwartz, C.C., 1984. Isolation of chlordecone binding proteins from pig liver cytosol. J. Toxicol. Environ. Health 14, 305317.

Lee, J., Scheri, R.C., Curtis, L.R., 2008. Soine, P.J., Blanke, R.V., Schwartz, C.C., 1983. Chlordecone Altered Hepatic Disposition of [14C]Cholesterol and Plasma Cholesterol Distribution but not SR-BI or ABCG8 Proteins in Livers of C57BL/6 Mice. Toxicol. Appl. Pharmacol. 229, 265-272. https://doi.org/10.1016/j.taap.2008.01.023

Levillain, J., Cattan, P., Colin, F., Voltz, M., Cabidoche, Y.-M., 2012. Analysis of environmental and farming factors of soil contamination by a persistent organic pollutant, chlordecone, in a banana production area of French West Indies. Agric. Ecosyst. Environ. 159, 123-132.

https://doi.org/10.1016/j.agee.2012.07.005

Markwell, M.A., Haas, S.M., Tolbert, N.E., Bieber, L.L., 1981. Protein determination in membrane and lipoprotein samples: manual and automated procedures. Methods Enzymol. 72, 296-303. https://doi.org/10.1016/s0076-6879(81)72018-4

Matolcsy, G., Nádasy, M., Andriska, V. (Eds.), 1988. Pesticide Chemistry. Elsevier.

Molowa, D.T., Shayne, A.G., Guzelian, P.S., 1986a. Purification and characterization of

Chlordecone metabolism in the pig. Toxicol. Lett. 17, 35-41.

\section{Acknowledgements}

The authors thank Régis Badin and Henri-Joël Affian for lipoprotein preparation. This study received financial support from the scientific research council A2F (University of Lorraine). Biomolecular interactions were investigated with the switchSENSE $\AA$ technology available at the ASIA platform (University of Lorraine - INRAE; https://a2f.univ-lorraine.fr/asia/).

\section{Supplementary data}

Supplementary data 1. SDS PAGE profile of lipoproteins. Apolipoprotein profiles of LDL (left) and HDL (right) were obtained by Coomassie blue staining after SDS PAGE, and confirm the presence of the major apolipoproteins apoB and apoAl for LDL and HDL, respectively. Molecular mass of standards are indicated for each gel. 
Supplementary data 2. Anion-exchange Fast Protein Liquid Chromatography of the 48-mer ssDNA-HDL (A) and ssDNA-LDL (B) conjugates using an ÄKTA-Start ${ }^{\mathrm{TM}}$ system. The fraction containing free lipoprotein eluted in the void volume, while the excess ssDNA eluted near the end of the $\mathrm{NaCl}$ gradient. The conjugate fractions were collected and concentrated to ca. $35 \mu \mathrm{L}$ prior to buffer exchange as explained in the Material and Methods section.

Supplementary data 3. Determination of the hydrodynamic diameter (DH) of HDL and LDL bound to the nanolever's distal end. The fluorescence response was measured by timecorrelated single-photon counting during the first $10 \mu s$ of upward switching. Orange and gray lines correspond to the actual data and best fit curve, respectively, of the reference; the blue and black curves correspond to the actual data and best fit curve, respectively, of HDL or LDL. Three measurements were carried out for each lipoprotein tested (Norm: normalized) 